\title{
PENGARUH KOMPETENSI GURU DAN LINGKUNGAN TEMAN SEBAYA TERHADAP PRESTASI BELAJAR SISWA
}

\section{Romadhoni Setyo Nugroho*}

Progam Studi Pendidikan Administrasi Perkantoran, FKIP, Universitas Sebelas Maret

\begin{abstract}
This research aims to identify: 1) The influence of Peer Group to Correspondence Achievement Students Of X Office Administration Class At SMK Negeri 1 Sukoharjo Academic Year 2016/2017, 2) The influence of Teacher Competence to Correspondence Achievement Students Of X Office Administration Class At SMK Negeri 1 Sukoharjo Academic Year 2016/2017, 3) The influence of Teacher Competence and Peer Group to Correspondence Achievement Students Of X Office Administration Class At SMK Negeri 1 Sukoharjo Academic Year 2016/2017. This research was an ex-post facto with quantitative approach. Research result: 1) Have a positive influence and significant of Teacher Competence to Correspondence Achievement by $r_{\mathrm{x}_{1} \mathrm{y}}=0,441 ; \mathrm{r}_{\mathrm{x}_{1} \mathrm{y}}^{2}==$ 0,$185 ; \mathrm{t}_{\text {count }} 4,449 ; \mathrm{t}_{\text {table }} 1,99$ with significantly of $5 \%$. 2) Have a positive influence and significant of Peer Group to Correspondence Achievement by $r_{x_{2} y}=0,425$; $\mathrm{r}_{\mathrm{x}_{2} \mathrm{y}}^{2}=0,171 ; \mathrm{t}_{\text {count }} 4,300 ; \mathrm{t}_{\text {table }} 1,99$ with significantly of $5 \% .3$ ) Have a positive influence and significant of teacher competence and Peer Group to Correspondence Achievement by $\mathrm{R}_{\mathrm{x}_{1} \mathrm{X}_{2} \mathrm{y}}=0,486 ; \mathrm{R}_{\mathrm{x}_{1} \mathrm{X}_{2} \mathrm{y}}^{2}=0,218 ; \mathrm{F}_{\text {count }} 12,849$; $\mathrm{F}_{\text {table }} 3,11$, with significantly of $5 \%$.
\end{abstract}

Key word: Teacher Competence, Peer Group, Student Achievement

Abstrak:Penelitian ini bertujuan untuk mengetahui: 1) Pengaruh Kelompok Peer Terhadap Prestasi Correspondence Siswa Kelas X Administrasi Perkantoran Di SMK Negeri 1 Sukoharjo Tahun Ajaran 2016/2017, 2) Pengaruh Kompetensi Guru Terhadap Prestasi Correspondence Siswa Kelas X Administrasi Perkantoran Di SMK Negeri 1 Sukoharjo Tahun Akademik 2016/2017, 3) Pengaruh Kompetensi Guru dan Kelompok Peer Terhadap Prestasi Correspondence Siswa Kelas X Administrasi Perkantoran Di SMK Negeri 1 Sukoharjo Tahun Ajaran 2016/2017. Penelitian ini merupakan penelitian ex - post facto dengan pendekatan kuantitatif. 5\%. 2) Memiliki pengaruh positif dan signifikan terhadap Peer Group terhadap Correspondence Achievement sebesar $r_{\mathrm{x}_{2} \mathrm{y}}=0,425 ; \mathrm{r}_{\mathrm{x}_{2} \mathrm{y}}^{2}=0,171 ; \mathrm{t}_{\text {count }} 4,300 ; \mathrm{t}_{\text {table }} 1,99 ; \mathrm{t}$ hitung $4.300 ;$ ttabel 1,99 dengan signifikan 5\%. 3) Memiliki pengaruh positif dan signifikan terhadap kompetensi guru dan Peer Group terhadap Correspondence Achievement sebesar $\mathrm{R}_{\mathrm{x}_{1} \mathrm{X}_{2} \mathrm{y}}=0,486 ; \mathrm{R}_{\mathrm{x}_{1} \mathrm{X}_{2} \mathrm{y}}^{2}=0,218 ; \mathrm{F}_{\text {count }} 12,849$ Jumlah $12.849 ; \mathrm{F}_{\text {tabel }} 3,11$, dengan signifikan $5 \%$.

Kata Kunci: Kompetensi Guru, Kelompok Peer, Prestasi Belajar Siswa

Alamat korespondensi: J1 Ir. Sutami 36 A Jebres Surakarta e-mail: romadonisetyo@gmail.com 


\section{PENDAHULUAN}

Pendidikan merupakan suatu hal yang sangat penting bagi masyarakat dan kemajuan bangsa. Untuk menghasilkan masyarakat atau generasi penerus bangsa yang memiliki kualitas unggul, maka pendidikan harus sesuai dengan fungsi dan tujuan pendidikan seperti yang tertulis di dalam Undang Undang No 20 Tahun 2003 tentang Sistem Pendidikan Nasional. Dari pengertian tersebut, untuk mencetak generasi penerus bangsa yang berkualitas, maka harus diimbangi dengan pendidikan yang sesuai dengan kebutuhan masyarakatnya dan dapat mengatasi masalah yang ada, baik itu masalah internal maupun eksternal. Sesuai dengan Undang - Undang No 20 Tahun 2003 tentang Sistem Pendidikan Nasional salah satu unsur penting yang mempengaruhi kemajuan pembangunan bangsa di masa mendatang adalah peserta didik. Seorang guru tentunya di dalam proses pembelajaran harus mampu menjalankan tugas dan perannya dengan baik, karena guru juga memiliki kontribusi yang besar dalam mencetak peserta didik yang berkualitas.
Salah satu indikator untuk mengukur kualitas dari peserta didik yaitu dapat melihatnya dari prestasi belajar siswa. Prestasi belajar merupakan suatu bentuk pencapaian atas usaha seseorang dalam penguasaan materi, keterampilan, maupun pengetahuan yang ditunjukkan ataupun diwakilkan dalam bentuk nilai. Salah satu indikator yang digunakan untuk mengukur prestasi belajar siswa dapat dilihat dari nilai UTS, yang biasanya diukur dengan cara diadakan tes hasil belajar. Ada kalanya hasil dari tes belajar siswa ada yang tinggi dan juga ada yang rendah.

Menurut Muhibbin Syah (2006: 132) Terdapat 2 faktor yang mempengaruhi Prestasi Belajar yaitu faktor eksternal (yang berasal dari luar) dan faktor internal (yang berasal dari dalam diri siswa). Faktor eksternal digolongkan menjadi faktor sosial dan faktor non Sosial. Sedangkan, faktor internal digolongkan menjadi faktor fisiologi dan faktor psikologi.

Salah satu faktor internal yang mempengaruhi Prestasi Belajar Siswa adalah persepsi siswa. Persepsi merupakan kesan yang diperoleh oleh individu melalui panca indera kemudian di 
analisa, di interpretasi dan kemudian dievaluasi, sehingga individu tersebut memperoleh makna. Salah satu persepsi siswa yang dapat mempengaruhi prestasi belajar siswa adalah persepsi tentang Kompetensi Guru. Berdasarkan penelitian yang dilakukan oleh Feryal (2010: 216) yang menyatakan bahwa guru yang professional harus dapat merangkul siswanya dalam pembelajaran yang berlangsung serta guru yang berkualitas harus komitmen untuk kemajuan siswa serta tujuan belajarnya, salah satunya guru harus memiliki kemampuan menggunakan berbagai metode pembelajaran sesuai dengan kondisi di dalam kelas, selain itu unsur yang juga penting adalah kompetensi afektif yang dimiliki guru, karena dalam penelitian tersebut jika guru memberikan dorongan yang cukup atau memberikan umpan balik ke siswa yang positif, siswa dapat lebih meningkatkan prestasi belajarnya. Dari penelitian tersebut, maka dapat dikatakan bahwa kompetensi yang dimiliki oleh guru juga memiliki pengaruh terhadap prestasi belajar siswa.

Hasil observasi yang dilakukan di kelas X Administrasi Perkantoran SMK Negeri 1 Sukoharjo, dengan melakukan wawancara dengan 3 siswa, menyatakan bahwa penerapan kompetensi yang dimiliki oleh guru masih kurang, seperti kurangnya variasi penerapan metode pembelajaran di dalam kelas dan kurangnya perhatian guru kepada siswa.

Faktor lainnya yang dapat mempengaruhi prestasi belajar siswa yaitu Lingkungan Teman Sebaya. Menurut Umar Tirtarahardja (2005: 181) "Lingkungan Teman Sebaya adalah suatu lingkungan yang terdiri dari orang yang bersamaan usianya". Menurut penelitian yang dilakukan Redi Indra Yudha \& Dr. Idris (2013:1) dalam sebuah lingkungan sekolah agar dapat mendukung kelancaran dalam proses pelaksanaan pembelajaran, hendaknya dapat memperhatikan kebutuhan akan sarana pendukung. Sehingga, siswa dapat mengembangkan kemampuan mereka dengan bantuan teman seusianya agar lebih termotivasi. Dalam meningkatkan hasil belajar, Lingkungan teman sebaya dapat dijumpai di lingkungan sekolah maupun tempat tinggalnya. Itu selaras dengan penelitian yang dilakukan oleh Bankole Emmanuel Temitope dan Ogunsakin, Funmi Christy (2015: 324) menyatakan bahwa lingkungan teman 
sebaya memiliki pengaruh yang besar terhadap tingkat akademik siswa. Teman sebaya merupakan lingkungan yang dapat mempengaruhi peserta didik, karena peserta didik berada di sekolah itu kurang lebih $8 \mathrm{jam} /$ hari sehingga memiliki kedekatan teman sebaya yang intensif dan akan membentuk suatu kelompok yang memiliki suatu ikatan yang kuat antar anggotanya dan seringkali antar anggota dapat tergantung antara satu sama lainnya, secara tidak langsung dengan adanya teman sebaya maka hal tersebut dapat mempengaruhi pola pikir, tingkah laku dan lain sebagainya dari siswa termasuk prestasi belajar dari siswa itu sendiri. Dengan adanya teman sebaya dapat memberikan dorongan dorongan yang positif terhadap prestasi belajar siswa seperti membentuk kelompok belajar siswa atau menjadikan teman sebaya untuk bertanya tentang materi pelajaran yang tidak dipahami oleh siswa sehingga prestasi belajar siswa meningkat. Para siswa yang tidak memiliki teman, kurang terlibat dalam perilaku prososial (kerja sama, berbagi dan membantu orang lain) mendapatkan nilai yang lebih rendah dan lebih sedih secara emosional (depresi dan kesejatheraan yang rendah) dibandingkan dengan siswa yang mempunyai lebih banyak teman (Santrock, 2009: 113)

Hasil observasi lingkungan teman sebaya yang ada di kelas X Administrasi Perkantoran SMK Negeri 1 Sukoharjo dari hasil wawancara dengan Ibu Sujiyani guru mata Pelajaran Korespondensi, menyatakan bahwa keadaannya masih kurang baik. Hal ini terlihat pada hasil wawancara dengan guru mata pelajaran Korespondensi. Saat kegiatan belajar mengajar pada mata pelajaran korespondensi berlangsung terlihat ada siswa yang berbicara dengan teman sebangku pada saat guru menjelaskan materi dan pada saat jam istirahat berakhir, ada beberapa siswa dan teman - temanya yang masuk terlambat pada saat pelajaran korespondensi berlangsung.

\section{METODE PENELITIAN}

Penelitian ini merupakan penelitian ex-post facto dengan pendekatan kuantitatif. Populasi dalam penelitian ini adalah siswa Kelas X Administrasi Perkantoran SMK Negeri 1 Sukoharjo Tahun Ajaran 2016 / 2017 sejumlah 109 siswa, teknik pengambilan sampel 
menggunakan teknik proporsional random sampling, dengan rumus Slovin diperoleh sampel sejumlah 86 siswa. Teknik pengumpulan data menggunakan dokumentasi dan angket.

Tabel 1. Jumlah Sampel Penelitian

\begin{tabular}{lll} 
No & Kelas & Jumlah \\
\hline $\mathbf{1}$ & X AP 1 & 28 \\
$\mathbf{2}$ & X AP 2 & 29 \\
$\mathbf{3}$ & X AP 3 & 29 \\
& Jumlah & 86
\end{tabular}

\section{PEMBAHASAN}

Di dalam penelitian ini terdapat 2 variabel bebas dan 1 variabel terikat. 2 variabel bebas tersebut adalah kompetensi guru dan lingkungan teman sebaya, sedangkan untuk variabel terikat dalam penelitian ini adalah prestasi belajar siswa. Untuk data prestasi belajar siswa diambil dari nilai Ulangan Tengah Semester 2 kelas $\mathrm{X}$ Administrasi Perkantoran SMK Negeri 1 Sukoharjo Tahun Ajaran 2016 / 2017 sejumlah 86 siswa. Untuk mengukur kompetensi guru di dalam penelitian ini, peneliti menggunakan data yang diperoleh dari angket penelitian kompetensi guru yang berjumlah 25 butir pertanyaan yang skala peniliannya menggunakan skala likert yang telah dimodifikasi. Angket penelitian tentang Kompetensi Guru, memiliki skor minimum sebesar 69 dan memiliki skor maximum sebesar 93. Memiliki arti bahwa skor angket tersebut memiliki rentang skor sebesar 24 rentang skor, Angket penelitian tersebut juga memiliki rerata skor sebesar 81, 22 serta memiliki standart deviation sebesar 4, 731. Dari hasil penelitian, peneliti menemukan hal yang penting yaitu di ketahui bahwa 90, 70\% kompetensi guru dalam melaksanakan kegiatan pembelajaran baik, dan 9, 30\% kompetensi guru dalam melaksanakan kegiatan pembelajaran cukup baik. Dari hal tersebut dapat diketahui bahwa kompetensi guru pada mata pelajaran Korespondensi kelas X Administrasi Perkantoran SMK Negeri 1 Sukoharjo Tahun 2016/2017 dinilai siswa sudah dalam kondisi cukup baik. Tetapi masih belum maksimal.

Untuk mengukur variabel lingkungan teman sebaya di dalam penelitian ini, peneliti menggunakan data yang diperoleh dari angket penelitian kompetensi guru yang berjumlah 23 butir pertanyaan dengan skala penilaiannya menggunakan skala Likert yang telah dimodifikasi. Angket penelitian tentang 
Kompetensi Guru, memiliki skor minimum sebesar 62 dan memiliki skor maximum sebesar 81. Memiliki arti bahwa skor angket tersebut memiliki rentang skor sebesar 19 rentang skor. Angket penelitian tersebut juga memiliki rerata skor sebesar 70.36 serta memiliki standart deviation sebesar 4.011. Dari hasil penelitian, peneliti menemukan hal yang penting yaitu di ketahui bahwa 83, $72 \%$ siswa menilai bahwa lingkungan teman sebaya sekolah tergolong baik, dan 16, $28 \%$ siswa menilai bahwa lingkungan teman sebaya di lingkungan sekolah tergolong cukup baik. Dari hal tersebut dapat diketahui bahwa lingkungan teman sebaya pada mata pelajaran Korespondensi kelas X Administrasi Perkantoran SMK Negeri 1 Sukoharjo Tahun 2016/2017 dinilai siswa sudah dalam kondisi cukup baik. Tetapi masih belum maksimal.

Untuk mengukur variabel prestasi belajar siswa di dalam penelitian ini, peneliti menggunakan data yang diperoleh dari nilai Ulangan Tengah Semester 2 Kelas X Administrasi Perkantoran pada Mata Pelajaran Korespondensi. Angket penelitian tentang Prestasi Belajar Siswa, memiliki skor minimum sebesar 60 dan memiliki skor maximum sebesar 92. Memiliki arti bahwa skor angket tersebut memiliki rentang skor sebesar 32 rentang skor. Angket penelitian tersebut juga memiliki rerata skor sebesar 75.28 serta memiliki standart deviation sebesar 6.714. Untuk nilai Ulangan Tengah Semester 2 Kelas X Administrasi Perkantoran pada Mata Pelajaran Korespondensi 49\% mencapai KKM, sedangkan $51 \%$ belum mencapai KKM.

Dalam penelitian ini menggunakan tiga uji prasyarat analisis, yaitu uji normalitas, uji liniearitas, dan uji multikoliniearitas. Pengujian normalitas data digunakan untuk menguji apakah data kontinyu berdistribusi normal sehingga analisis dengan regresi dapat dilakukan. Pengujian normalitas data digunakan untuk menguji apakah data kontinyu berdistribusi normal sehingga analisis dengan regresi dapat dilakukan. dapat diketahui bahwa variabel kompetensi guru memiliki Asymp sign 0,200 > 0, 05, sehingga variabel Kompetensi Guru dapat dikatakan berdistribusi normal, sedangkan hasil uji normalitas lingkungan teman sebaya memiliki Asymp sign 0,098>0, 05, sehingga variabel 
Lingkungan Teman Sebaya dapat dikatakan berdistribusi normal, diketahui bahwa variabel prestasi belajar siswa memiliki Asymp sign 0,138 >0, 05 sehingga variabel Prestasi Belajar Siswa dapat dikatakan berdistribusi normal. Uji linieritas dilakukan untuk mengetahui hubungan variabel bebas dan variabel terikat itu linier. Dari hasil di dapat bahwa nilai signifikan $F_{\text {hitung kompetensi }}$ guru terhadap prestasi belajar sebesar 0 , $441>$ dari 0, 05 maka hal tersebut liniear sedangkan, nilai signifikan $F_{\text {hitung }}$ lingkungan teman sebaya terhadap prestasi belajar sebesar 0, $282>$ dari 0,05 maka hal tersebut liniear. Hasil uji multikoliniearitas dengan menggunakan uji VIF adalah nilai tolerance sebesar 0,657> 0, 10 dan nilai VIF Menunjukkan $1,523<10$, melihat dari hasil tersebut maka variabel kompetensi guru dan lingkungan teman sebaya tidak memiliki hubungan multikoliniearitas.

\section{Pengaruh Kompetensi Guru Terhadap Prestasi Belajar Siswa. \\ Berdasarkan hasil analisis dengan} menggunakan uji regresi sederhana maka di peroleh $t_{\text {hitung }}=4$, 497, sedangkan tabel $=1,99$, sehingga di peroleh 4, $497>1,99$, sehingga dapat dikatakan bahwa hubungan kompetensi guru terhadap prestasi belajar siswa pada Mata Pelajaran Korespondensi Kelas X Administrasi Perkantoran SMK Negeri 1

Sukoharjo Tahun Ajaran 2016/2017 signifikan . Diketahui bahwa koefisien korelasi dari kompetensi guru terhadap prestasi belajar siswa sebesar 0 , 441, sehingga hal tersebut menunjukkan bahwa hubungan kompetensi guru terhadap prestasi belajar siswa memiliki hubungan yang positif. Itu artinya bahwa hal tersebut menunjukkan bahwa kompetensi guru berpengaruh positif, yang artinya adalah jika kompetensi guru baik, maka hal tersebut akan meningkatkan prestasi belajar siswa. Itu artinya seorang guru juga berpengaruh dalam pencapaian prestasi belajar dari siswa yang dibimbing di dalam kelasnya, tentunya agar proses belajar mengajar yang terjadi di dalam kelas sesuai dengan tujuannya, tentunya seorang guru harus mempunyai kualitas yang baik, sehingga materi yang disampaikan oleh guru dapat diterima oleh peserta didiknya. Agar proses belajar mengajar yang terjadi di dalam kelas kondusif, tenang dan sesuai tujuannya, maka seorang guru harus menerapkan kompetensi yang dimiliki 
sesuai dengan kondisi kelas saat itu. Sehingga dengan hal tersebut, maka diharapkan siswa merasa nyaman, dan tenang terhadap proses belajar mengajar yang berlangsung.

Untuk sumbangan efektif yang diberikan oleh kompetensi guru sebesar $12,71 \%$. Dari hasil tersebut maka kompetensi guru lebih dominan mempengaruhi prestasi belajar siswa kelas X SMK Negeri 1 Sukoharjo pada Mata Pelajaran Korespondensi dibandingkan lingkungan teman sebaya siswa. Hal ini menunjukkan bahwa prestasi belajar siswa lebih cenderung dipengaruhi oleh kompetensi yang dimiliki oleh gurunya dibandingkan lingkungan teman sebaya yang ad a di SMK Negeri 1 Sukoharjo. Hal penting lainnya adalah 90, 70\% kompetensi guru dalam melaksanakan kegiatan pembelajaran baik, dan 9, 30\% kompetensi guru dalam melaksanakan kegiatan pembelajaran cukup baik.

Hasil penelitian ini sejalan dengan hasil penelitian terdahulu yaitu penelitian yang dilakukan oleh Aga Dwi Sinta dengan masalah Pengaruh Kompetensi Guru dan Motivasi Berprestasi Siswa Terhadap Prestasi Belajar pada
Mata Pelajaran Pengelolaan Usaha Pemasaran Kelas X PM Di SMK Negeri 1 Karanganyar Tahun Ajaran 2015/ 2016. Hasil yang disampaikan dalam penelitian tersebut adalah kompetensi guru berpengaruh positif terhadap prestasi belajar pada Mata Pelajaran Pengelolaan Usaha Pemasaran Kelas X PM di SMK Negeri 1 Karanganyar Tahun Aja-

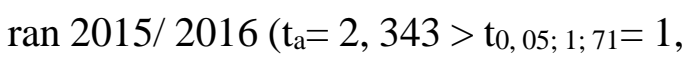
667) sebesar 7, $34 \%$.

\section{Pengaruh Lingkungan Teman Sebaya Terhadap Prestasi Belajar Siswa}

Berdasarkan hasil analisis dengan menggunakan uji regresi sederhana maka di peroleh $t_{\text {hitung }}=4,300$, sedangkan $\mathrm{t}_{\text {tabel }}=1,99$, sehingga di peroleh $4,300>1$, 99, sehingga dapat dikatakan bahwa hubungan kompetensi lingkungan teman sebaya terhadap prestasi belajar siswa memiliki hubungan yang signifikan. Diketahui bahwa koefisien korelasi dari lingkungan teman sebaya terhadap prestasi belajar siswa sebesar 0,425 , sehingga hal tersebut menunjukkan bahwa hubungan lingkungan teman sebaya terhadap prestasi belajar siswa memiliki hubungan yang positif sehingga hal tersebut menunjukkan bahwa 
hubungan lingkungan teman sebaya terhadap prestasi belajar siswa memiliki hubungan yang positif. Itu artinya bahwa hal tersebut menunjukkan bahwa lingkungan teman sebaya berpengaruh positif, yang artinya adalah jika lingkungan teman sebaya baik, maka hal tersebut akan dapat meningkatkan prestasi belajar siswa. Artinya adalah Teman sebaya merupakan faktor yang juga dapat mempengaruhi prestasi belajar siswa. Kelompok teman sebaya merupakan kelompok yang dimana anggota - anggotanya memiliki kesamaan (baik itu usia maupun kedudukan), dengan kata lain, dengan adanya teman sebaya akan terjadi interaksi secara intens antar anggotanya, yang akan menimbulkan ikatan yang kuat antara anggota satu dengan anggota lainnya. Seringkali dengan adanya teman sebaya, maka diantara anggota anggotanya akan timbul ketergantungan satu sama lain.

Oleh karena itu, maka lingkungan teman sebaya dapat mempengaruhi pola pikir dan tingkah laku dari siswa atau peserta didik, termasuk juga dapat mempengaruhi prestasi belajar siswa. Lingkungan teman sebaya dapat memberikan pengaruh yang positif terhadap siswa, misalnya membentuk kelompok belajar, sebagai sumber informasi bagi siswa yang tidak memahami pelajaran dan lain sebagainya. Dari contoh tersebut, maka hal tersebut juga dapat mempengaruhi prestasi belajar siswa, dan diharapkan prestasi belajar siswa meningkat atau tinggi.

Sumbangan efektif yang diberikan oleh lingkungan teman sebaya sebesar 9,09\%. Dari hasil tersebut maka lingkungan teman sebaya juga dapat mempengaruhi prestasi belajar siswa kelas X SMK Negeri 1 Sukoharjo pada Mata Pelajaran Korespondensi. Hal ini menunjukkan bahwa prestasi belajar siswa juga dapat dipengaruhi oleh lingkungan teman sebaya yang dimiliki oleh siswa kelas X Administrasi Perkantoran SMK Negeri 1 Sukoharjo. Hal penting lainnya adalah $83,72 \%$ siswa menilai bahwa lingkungan teman sebaya sekolah tergolong baik, dan 16, $28 \%$ siswa menilai bahwa lingkungan teman sebaya di lingkungan sekolah tergolong cukup baik. Dari hal tersebut dapat diketahui bahwa lingkungan teman sebaya pada mata pelajaran Korespondesi kelas $\mathrm{X}$ Administrasi Perkantoran SMK Negeri 1 
Sukoharjo Tahun 2016/2017 dinilai siswa sudah dalam kondisi cukup baik.

Hasil penelitian ini sejalan dengan hasil penelitian terdahulu yaitu penelitian yang dilakukan oleh Danti Indri Astuti dengan masalah Pengaruh Pergaulan Kelompok Teman Sebaya Dan Motivasi Belajar Terhadap Prestasi Belajar Akuntansi Siswa Kelas XI IPS SMA Negeri 1 Parakan Tahun Ajaran 2015/2016. Dari hasil penelitian tersebut menyatakan bahwa pengaruh positif dan signifikan Pergaulan Kelompok Teman Sebaya terhadap Prestasi Belajar Akuntansi Siswa Kelas XI IPS SMA Negeri 1 Parakan Tahun Ajaran 2015/2016 dengan $r_{x_{1} y}=0,421 ; r_{x_{1} y}^{2}=$ 0,177 ; thitung 4,592 ; tabel 1,985 pada taraf signifikansi $5 \%$.

\section{Pengaruh Kompetensi Guru dan Lingkungan Teman Sebaya Terhadap Prestasi Belajar Siswa.}

Berdasarkan hasil analisis dengan menggunakan uji regresi berganda maka di peroleh koefisien korelasi dari kompetensi guru dan lingkungan teman sebaya terhadap prestasi belajar siswa sebesar 0,486 , sehingga hal tersebut menunjukkan bahwa hubungan kompetensi guru dan lingkungan teman sebaya secara bersama - sama terhadap prestasi belajar siswa memiliki hubungan yang positif. Selain itu korelasi determinasi diketahui sebesar 0, 218 . Setelah dilakukan uji $\mathrm{F}$ maka diperoleh F hitung dari table diatas sebesar 11,753 sedangkangkan untuk $\mathrm{F}_{\text {tabel }}$ sebesar 3, 11 . Hal tersebut menunjukkan bahwa hubungan kompetensi guru dan lingkungan teman sebaya secara bersama - sama terhadap prestasi belajar siswa Kelas X Administrasi Perkantoran SMK Negeri 1 Sukoharjo pada mata pelajaran korespondensi memiliki hubungan yang signifikan.

Berdasarkan hasil analisis dengan menggunakan uji regresi berganda juga dapat diketahui bahwa sumbangan yang diberikan oleh Kompetensi Guru dan Lingkungan Teman Sebaya Terhadap Prestasi Belajar Siswa sebesar $21,8 \%$ sedangkan sisanya sebesar 78, 2 $\%$ dipengaruhi oleh variabel lain di luar penelitian ini misalnya seperti Perhatian, pengamatan, tanggapan, ingatan, berfikir, perasaan, lingkungan keluarga, lingkungan masyarakat, dan lain lainnya yang dapat mempengaruhi prestasi belajar siswa kelas X SMK Negeri 1 
Sukoharjo khususnya pada mata pelajaran korespondensi dari hasil tersebut menunjukkan bahwa variabel kompetensi guru dan variabel lingkungan teman sebaya tidak satu - satunya variabel yang dapat mempengaruhi prestasi belajar siswa. Meskipun begitu dengan persentase sebesar $21,8 \%$ tersebut menunjukkan bahwa semakin baik kompetensi yang dimiliki gurunya dan lingkungan teman yang dimiliki oleh siswa kelas X Administrasi Perkantoran SMK Negeri 1 Sukoharjo maka akan meningkatkan prestasi belajar siswanya khususnya pada mata pelajaran korespondensi, sehingga diharapkan guru dan kepala sekolah agar dapat memperhatikan dan meningkatkan kompetensi yang dimilikinya guna untuk membantu dalam proses belajar mengajar yang berlangsung dan memudahkan penyampaian materi pembelajaran yang disampaikan oleh guru, serta yang utama adalah untuk meningkatkan prestasi belajar siswa kelas $\mathrm{X}$ Administrasi Perkantoran SMK Negeri 1 Sukoharjo. Selain itu untuk siswa juga lebih selektif dalam berteman atau bergaul dengan teman - teman sebayanya serta diharapkan siswa juga dapat memberi dukungan kepada teman - temannya yan kesulitan dalam belajar siswa lainnya.

\section{KESIMPULAN}

Berdasarkan hasil peneliti-an dan pembahasan analisis data yang dapat, maka peneliti dapat menarik kesimpulan Ada pengaruh yang positif dan signifikan kompetensi guru terhadap prestasi belajar siswa kelas $\mathrm{X}$ Administrasi Perkantoran SMK Negeri 1 Sukoharjo pada mata pelajaran 2016 / 2017. Hal tersebut dapat diketahui dari hasil output regresi sederhana dari Kompetensi guru terhadap prestasi belajar siswa yang dapat dilihat dari hasil uji $\mathrm{t}$ yaitu $r_{x_{1} y}=0,441 ; r_{x_{1} y}^{2}=0,185 ; t_{\text {hitung }}$ $4,449>\mathrm{t}_{\text {tabel }} 1,99$ dari hasil perhitungan tersebut maka hipotesis yang diajukan oleh peneliti yaitu "Terdapat pengaruh kompetensi guru terhadap prestasi belajar siswa pada mata pelajaran Korespondensi kelas X Administrasi Perkantoran SMK Negeri 1 Sukoharjo Tahun Ajaran 2016 / 2017” dapat “diterima”.Ada pengaruh yang positif dan signifikan lingkungan teman sebaya terhadap prestasi belajar siswa kelas X Administrasi Perkantoran SMK Negeri 1 Sukoharjo pada mata pelajaran 2016/2017. Hal tersebut dapat diketahui dari hasil output 
regresi sederhana dari lingkungan teman sebaya terhadap prestasi belajar siswa yang dapat dilihat dari hasil uji t yaitu $r_{x_{2} y}=0,425 ; r_{x_{2} y}^{2}=0,171 ; t_{\text {hitung }} 4,300>$ $\mathrm{t}_{\text {tabel }}$ 1, 99, dari hasil perhitungan tersebut maka hipotesis yang diajukan oleh peneliti yaitu "Terdapat pengaruh lingkungan teman sebaya terhadap prestasi belajar siswa pada mata pelajaran Korespondensi kelas X Administrasi Perkantoran SMK Negeri 1 Sukoharjo Tahun Ajaran 2016 / 2017" dapat “diterima”.Ada pengaruh yang positif dan signifikan kompetensi guru dan lingkungan teman sebaya secara bersama sama terhadap prestasi belajar siswa kelas X Administrasi Perkantoran SMK Negeri 1 Sukoharjo pada mata pelajaran
2016 / 2017. Hal tersebut dapat diketahui dari hasil output regresi berganda dari Kompetensi guru dan lingkungan teman sebaya secara bersama - sama terhadap prestasi belajar siswa yang dapat dilihat dari hasil uji F yaitu $R_{x_{1} X_{2} y}=0,486$; $R_{x_{1} X_{2} y}^{2}=0,218$; F Fitung 12,849 ; > $\mathrm{F}_{\text {tabel }}$ 3,11 , dari hasil perhitungan tersebut maka hipotesis yang diajukan oleh peneliti yaitu "Terdapat pengaruh kompetensi guru dan lingkungan teman sebaya secara bersama - sama terhadap prestasi belajar siswa pada mata pelajaran Korespondensi kelas X Administrasi Perkantoran SMK Negeri 1 Sukoharjo Tahun Ajaran 2016 / 2017” dapat "diterima".

\section{DAFTAR PUSTAKA}

Depdiknas. (2003). Undang-Undang Nomor 20 tentang Sistem Pendidikan Nasional. Jakarta

Syah, Muhibbin. (2006). Psikologi Pendidikan Dengan Pendekatan Baru. Bandung: PT Remaja Rosdakarya

Cubukcu, Feryal. (2010). Student Teachers' Perceptions Of Teacher Competence And Their Attributions For Success And Failure In Learning. Journal of International Social Research,

Umar Tirtarahardja, La Sulo. (2005). Pengantar Pendidikan. Jakarta: Rineka Cipta

Yudha, Redi Indra \& Idris. (2013).” Pengaruh Lingkungan Sekolah, Teman Sebaya dan Motivasi Belajar Terhadap Hasil Belajar Siswa Pada SMK Bidang Manajemen Bisnis Jurusan Pemasarandi Kecamatan Jambi Selatan Kota 
Jambi”. Jurnal. Padang: Program Studi Magister Pendidikan Ekonomi Universitas Negeri Padang

Temitope, B. E., \& Christy, O. F. (2015). Influence of Peer Group on Academic Performance of Secondary School Students in Ekiti State, International Journal Of Innovative Research \& Development, 4 (1), 324 - 331.

Santrock, John W. (2009). Psikologi Pendidikan. Jakarta: Salemba Humanika 